\title{
IMPLEMENTASI PROGRAM PEMELIHARAAN JALAN DI DINAS PEKERJAAN UMUM DAN PENATAAN RUANG (PUPR) DI KABUPATEN PANDEGLANG
}

\author{
Rachmi Yulianti dan Budi Hasanah \\ Prodi Administrasi Publik FISIPKUM Universitas Serang Raya \\ Jl. Raya Serang - Cilegon Km. 05 (Taman Drangong), Serang - Banten \\ e-mail : rachmiyulianti77@gmail.com
}

\begin{abstract}
Abstrak
Penelitian ini bertujuan untuk mengetahui Implementasi Program Pemeliharaan Jalan di Dinas Pekerjaan Umum dan Penataan Ruang (PUPR) Kabupaten Pandeglang (Studi kasus Kecamatan Pandeglang). Metode penelitian ini adalah kualitatif deskriptif. Teknik pengumpulan data yang digunakan adalah: Wawancara, observasi, dokumentasi. Lokasi penelitian Dinas Pekerjaan Umum dan Penataan Ruang (PUPR) Kabupaten Pandeglang dan Kecamatan Pandeglang. Berdasarkan hasil penelitian dapat disimpulkan bahwa: 1)Implementasi program Pemeliharaan Jalan di Dinas Pekerjaan Umum dan Penataan Ruang (PUPR) Kabupaten Pandeglang (Studi kasus Kecamatan Pandeglang) sudah berjalan dengan baik karena program yang direncanakan sudah di realisasikan tahun 2017 dan disesuaikan dengan anggaran yang diberikan kepada Dinas PUPR tetapi memang tidak semua bisa dilaksanakan pemeliharaan. 2)Faktor pendukung yaitu kemungkinan adanya pembiayaan infrastruktur yang bisa di dapatkan tidak hanya dari APBD tapi adanya bantuan dari Dana Alokasi Khusus (DAK), APBN, bantuan dari provinsi serta sumberdaya manusia dan aturan yang berlaku. Faktor penghambat dari implementasi tentu anggaran yang kurang tetapi ruas jalan banyak yang harus ditangani sehingga tidak cepat ditanganinya, cuaca yang tidak disangka bisa memperlambat perbaikan
\end{abstract}

Kata kunci : Implementasi, Program, Pemeliharaan Jalan

\begin{abstract}
This study aims to determine the Implementation of Road Maintenance Programs in the Public Works and Spatial Planning (PUPR) Service of Pandeglang District (Case Study in Pandeglang District). This research method is descriptive qualitative. Data collection techniques used are: Interview, observation, documentation. Research location of the Public Works and Spatial Planning (PUPR) Office of Pandeglang Regency and Pandeglang District. Based on the results of the study it can be concluded that: 1) Implementation of Road Maintenance programs in the Public Works and Spatial Planning (PUPR) Service of Pandeglang District (Pandeglang District Case Study) has been going well because the planned program has been realized in 2017 and adjusted to the given budget to the PUPR Service but not all maintenance can be carried out. 2) Supporting factors, namely the possibility of infrastructure funding that can be obtained not only from the APBD but the assistance from the Special Allocation Fund (DAK), the National Budget, assistance from the province and human resources and applicable regulations. The inhibiting factor of the implementation is of course the budget that is lacking but many roads must be handled so that it is not handled quickly, unexpected weather can slow down repairs
\end{abstract}

Keywords: Implementation, Program, Road Maintenance

Implementasi Program Pemeliharaan Jalan di Dinas Pekerjaan Umum dan Penataan Ruang (PUPR)

Kabupaten Pandeglang 


\section{PENDAHULUAN}

Semakin banyak nya jumlah kendaraan bermotor di Indonesia harus di dukung oleh sarana prasarana jalan yang baik, aman dan nyaman. Keberadaan jalan raya yang menghubungkan antar wilayah sangat berperan sebagai jalur pendistribusian barang dan jasa melaui transportasi darat. Hal ini perlu mendapat perhatian kita semua sebagai sebuah kebutuhan yang dapat dikatakan dasar. Indonesia sebagai salah satu negara berkembang dengan jumlah penduduk kelima terbanyak di Asia Tenggara, sedikit banyaknya telah mengalami peningkatan dalam intensitas aktivitas sosial ekonomi seiring dengan kemajuan ekonomi yang telah terjadi. Aktivitas masyarakat seiring dengan jumlah penduduk yang semakin meningkat disuatu wilayah merupakan faktor utama pembangkit kebutuhan perjalanan yang memerlukan adanya tingkat efisiensi, keamanan, serta kenyamanan dalam perjalanan. Peningkatan jumlah pergerakan yang terjadi juga akan menuntut kualitas maupun kuantitas prasarana penunjang yang seimbang.

Meningkatknya aktivitas dalam kehidupan sosial masyarakat, peranan jalan akan semakin meningkat pula, saat ini jalan bukan hanya untuk mempermudah pergerakan orang, barang dan jasa melainkan berkaitan juga dengan kehidupan sosial, ekonomi, dan budaya serta lingkungan dan dikembangkan melalui pendekatan pengembangan wilayah agar tercapainya keseimbangan dana pemerataan pembangunan antar daerah, membentuk dan memperkokoh kesatuan nasional untuk memantapkan pertahanan dan keamanan nasional, serta membentuk struktur ruang dalam rangka mewujudkan sasaran pembangunan nasional, sebagaimana yang tertulis dalam Peraturan Menteri Pekerjaan Umum, Nomor : 13/PRT/M/2011 Tentang Tata Cara Pemeliharaan Jalan dan Penilikan disebutkan Pasal 1 bahwa Pemeliharaan jalan, pemeliharaan rutin jalan, pemeliharaan rutin berkala jalan, dan rehabilitasi jalan. Pasal 23 menyebutkan tentang penyelenggaraan jalan nasional, jalan provinsi dan jalan kabupaten/kota. Pasal 25 menyebutkan bahwa masyarakat dapat berperan serta dalam pemeliharaan jalan, peran masyarakat dalam pelaksanaan pemeliharaan jalan sebagaimana dijelaskan pada ayat (1) adalah peran serta orang atau instansi sepanjang tidak merugikan kepentingan umum.

Keberhasilan suatu implementasi kebijakan dapat diukur atau dilihat dari proses dan pencapaian tujuan hasil akhir (output) yaitu : tercapai atau tidaknya tujuan-tujuan yang ingin diraih. Hal ini tak jauh berbeda dengan apa yang diutarakan oleh Meriee S. Grindle (1980) " pengukuran keberhasilan implementasi dapat dilihat dari prosesnya, dengan mempertanyakan apakah pelaksanaan program sesuai dengan yang telah ditentukan yaitu melihat pada action program dari individual project dan yang kedua apakah tujuan program tersebut tercapai". Mengutip dari buku dasar-dasar kebijakan publik (Leo agustino. 2012 : 139)

Secara cepat atau lambat jalan akan mengalami penurunan tingkat pelayanan. Menurunnya tingkat pelayanan jalan akan ditandai dengan adanya kerusakan pada jalan, kerusakan yang terjadi juga bervariasi pada setiap segmen di sepanjang ruas jalan apabila dibiarkan dalam jangka waktu yang lama, maka akan semakin memperparah kerusakan ruas jalan itu sendiri dan akan memberikan rasa kurang aman dan nyaman terhadap pengguna jalan. Pada dasarnya setiap wilayah akan mengalami penurunan dan berusaha untuk terus menuju proses tumbuh dan berkembang sebagai jawaban atas berkembangnya kebutuhan masyarakat kota, Kabupaten atau wilayah yang mampu memberi lahan penghidupan yang layak. Salah satu tolak ukur yang menjadi keberhasilan suatu program dapat dilihat dari akses lalu lintasnya, karena fasilitas jalan sangat mempengaruhi investor agar para investor tertarik untuk berkunjung dan menanamkan modalnya sehingga APBD akan meningkat. 
Selaras dengan hal pemeliharaan jalan yang rusak, Pemerintah Kabupaten Pandeglang khususnya dinas Pekerjaan Umum dan Penataan Ruang (PUPR) berperan penting dalam pemeliharaan dan perbaikan jalan terutama daerah yang dinilai sangat mendukung dalam meningkatkan pembangunan daerah. Terkait dengan pembangunan di segala sektor, masih banyak pembangunan lain yang kurang terpelihara dengan baik khususnya tentang pemeliharaan jalan yang ternyata masih banyak kerusakannya. karena dengan adanya pemeliharaan, jalan yang tadinya rusak parah akan di benahi dan di perbaiki dengan baik maka akan memberikan kenyamanan dan keamanan bagi pengguna jalan khususnya warga Kabupaten Pandeglang.
Melihat fenomena keberadaan prasarana jalan raya di wilayah Kabupaten Pandeglang masih banyak yang kurang terpelihara dan masih ada jalanan yang rusak sehingga dapat menimbulkan kesan suatu daerah menjadi kumuh dan merasa terbelakang serta bisa menghambat suatu laju perkembangan sosial masyarakat atau pertumbuhan perekonomian di daerah tersebut yang akan berdampak pada terhambatnya perkembangan ekonomi bagi masyarakat Kabupaten Pandeglang.

Adapun ruas jalan di Kabupaten Pandeglang yang disesuaikan dengan Keputusan Bupati Pandeglang Nomor 620 Tahun 2009 tentang Daftar Jalan Kabupaten Pandeglang antara lain

Tabel 1

Daftar Ruas Jalan Kabupaten Pandeglang

\begin{tabular}{ccc}
\hline No & Nama Jalan & $\begin{array}{c}\text { Panjang ruas } \\
(\mathrm{km})\end{array}$ \\
1 & Bama - Ppagelaran - Pasir Kadu & 15.50 \\
2 & Sudimanik - Curug & 9.50 \\
3 & Padali - Pasir Nangka & 11.10 \\
4 & Pasar Nangka - Ciaer Jeruk & 14.00 \\
5 & Sumur - Taman Jaya & 12.00 \\
6 & Marapat - Camara & 13.40 \\
7 & Cikadu - Pasir nangka & 12.40 \\
\hline
\end{tabular}

Sumber: Dinas Pekerjaan Umum dan Penataan Ruang (PUPR), 2017

Dari tabel 1 diatas menunjukan panjang ruas jalan di antaranya, BamaPagelaran-Pandeglang panjang ruas $15,50 \mathrm{~km}$, Sudimanik-Curug panjang ruas $9,50 \mathrm{~km}$, Padali-Pasir Nangka panjang ruas 11,10 km, Psr Nangka-Ciaer Jeruk panjang ruas $14,00 \mathrm{~km}$, Sumur-Taman Jaya panjang ruas $12,00 \mathrm{~km}$, Marapat-Camara panjang ruas $13,40 \mathrm{~km}$, Cikadu-Pasir Nangka panjang ruas 12,40

Tabel 2

\section{Klasifikasi daftar jalan rusak di Kabupaten Pandeglang tahun 2016}

\begin{tabular}{ccccc}
\hline No & Ruas Jalan & Kecamatan & $\begin{array}{c}\text { Panjang } \\
\text { ruas }\end{array}$ & Kondisi \\
1 & $\begin{array}{c}\text { Karangtanjung }- \\
\text { Sukarehe }\end{array}$ & Karangtanjung & 2.50 & Baik/Sedang \\
& $\begin{array}{c}\text { Sukarehe - Nanggor (Bts } \\
\text { Kab Serang) }\end{array}$ & Karangtanjung & 2.80 & Baik/Sedang \\
3 & Kadumerak-Sampora & Karangtanjung & 3.00 & Baik \\
\hline
\end{tabular}




\begin{tabular}{|c|c|c|c|c|}
\hline 4 & Pabrik-Sampora & Karangtanjung & 2.50 & Baik \\
\hline 5 & $\begin{array}{c}\text { Sukarehe - Sabitangtu } \\
\text { (TPA) }\end{array}$ & Karangtanjung & 3.70 & Baik/Sedang \\
\hline 6 & Sabi - Sabitangtu & Karangtanjung & 2.00 & Baik/Sedang \\
\hline 7 & Juhut-Canggoang & Karangtanjung & 3.00 & Baik/Sedang \\
\hline 8 & Lintas Timur - Sabitangtu & Karangtanjung & 3.00 & Rusak \\
\hline 9 & $\begin{array}{c}\text { Kadumerak - Lintas } \\
\text { Timur }\end{array}$ & Karangtanjung & 3.00 & Rusak \\
\hline 10 & $\begin{array}{l}\text { Kalahang - } \\
\text { Karangtanjung }\end{array}$ & Karangtanjung & 3.00 & Sedang/Rusak \\
\hline 11 & Pandeglang - Cicadas & Pandeglang & 1.85 & Sedang/ rusak \\
\hline 12 & Cicadas - Pasirpeuteuy & Pandeglang & 2.50 & Baik/Sedang \\
\hline 13 & $\begin{array}{l}\text { Pasirpeuteuy - } \\
\text { Kaduengang }\end{array}$ & Pandeglang & 7.55 & Sedang/Rusak \\
\hline 14 & Pabuaran - Wates & Pandeglang & 5.00 & Rusak \\
\hline 15 & Kadomas - Pabuaran & Pandeglang & 2.50 & Baik/Sedang \\
\hline 16 & Maja - Cikole & Majasari & 1.40 & Baik/Sedang \\
\hline 17 & Cikole - Cinunggal & Majasari & 1.00 & Sedang/Rusak \\
\hline 18 & Pagerbatu - Pasirangin & Majasari & 1.00 & Sedang/Rusak \\
\hline 19 & Ciekek - Pagerbatu & Majasari & 5.00 & Baik/Sedang \\
\hline 20 & $\begin{array}{l}\text { Cidangiang - Maja } \\
\text { Masjid }\end{array}$ & Majasari & 0.90 & Rusak \\
\hline 21 & Maja - Kuranten & Majasari & 1.80 & Sedang \\
\hline 22 & Kuranten - Pagerbatu & Majasari & 1.60 & Baik/Sedang \\
\hline 23 & Ciekek - Kadomas & Majasari & 1.40 & Baik \\
\hline 24 & Pasirangin - Pakuhaji & Majasari & 3.20 & Sedang \\
\hline 25 & $\begin{array}{c}\text { Maja Teluklada - } \\
\text { Samaboa }\end{array}$ & Majasari & 1.80 & Baik/Sedang \\
\hline 26 & Kuranteun - Stadion & Majasari & 0.70 & Rusak \\
\hline 27 & $\begin{array}{c}\text { Cipacung Girang - } \\
\text { Stadion }\end{array}$ & Majasari & 0.50 & Rusak \\
\hline
\end{tabular}

Sumber : Pekerjaan Umum dan Penataan Ruang (PUPR)

Dari tabel 2 diatas menunjukan bahwa dari Kecamatan Pandeglang ada sekitar 5 (lima) jalan yaitu Pandeglang -Cicadas panjang ruas $1,85 \mathrm{~km}$ dengan kondisi Sedang /Rusak, Cicadas-Pasirpeuteuy panjang ruas
2,50 km dengan kondisi Baik/Sedang, Pasirpeuteuy- Kaduengang panjang ruas 7,55 km dengan kondisi Sedang/Rusak, PabuaranWates panjang ruas $5,00 \mathrm{~km}$ dengan kondisi Rusak, Kadomas-Pabuaran panjang ruas 2,50 $\mathrm{km}$ dengan kondisi Baik/Sedang 

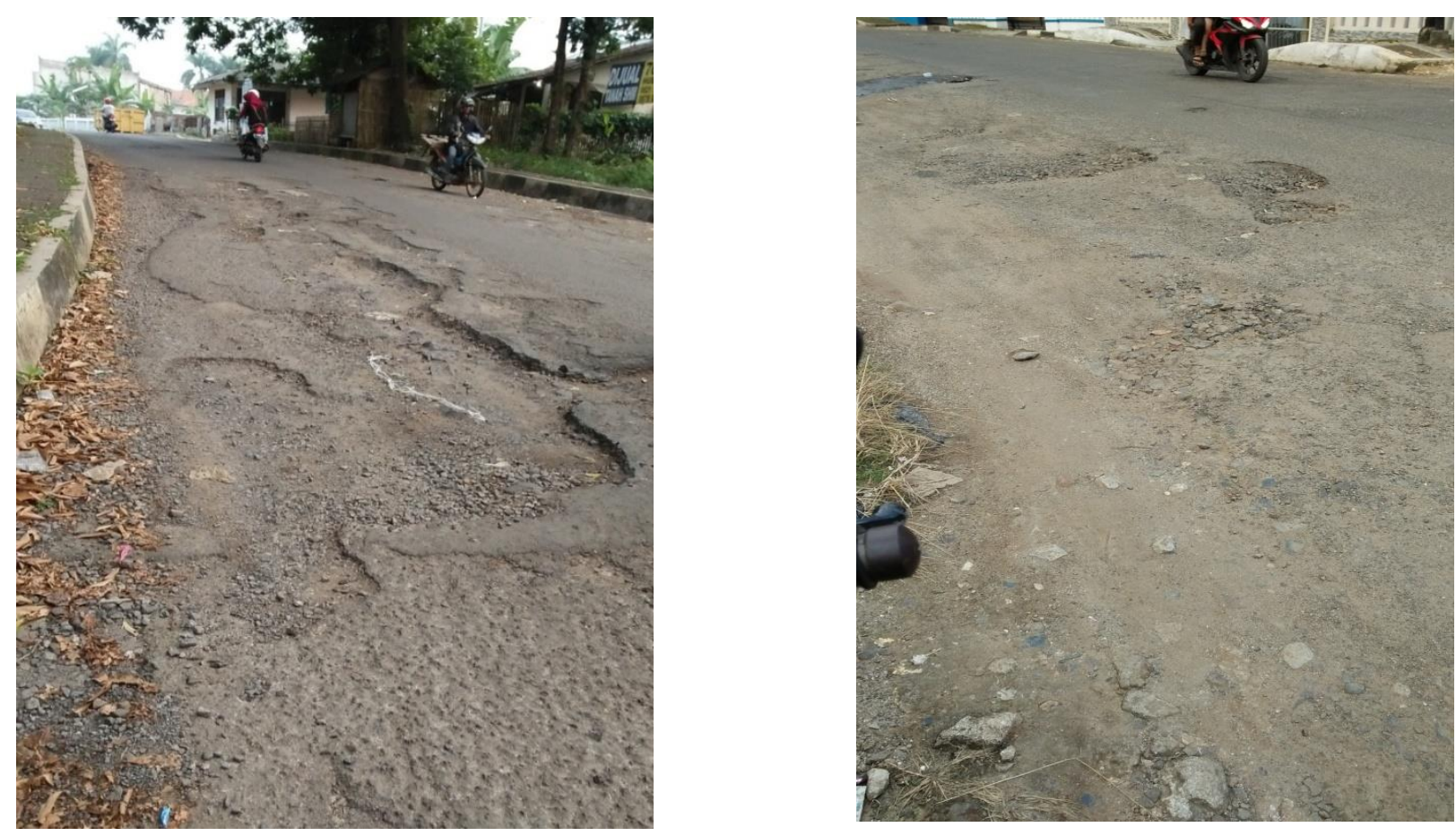

\section{Gambar 1}

Kondisi Jalan yang masih Rusak di kabayan, Kecamatan Pandeglang


\section{Gambar 2}

Kondisi Jalan yang masih rusak di Cicadas, Kecamatan Pandeglang

Berdasarkan informasi dari Dinas Pekerjaan Umum dan Penataan Ruang (PUPR) kabupaten Pandeglang bidang pemeliharaan jalan ada beberapa hambatan untuk menangani tingkat kerusakan melebihi kapasitas lebih dari 10 persen hanya untuk pemeliharaan jalan, sedangkan Dinas Pekerjaan Umum dan Penataan Ruang (PUPR) hanya bisa menangani kurang dari 10 persen kerusakannya hanya bisa beberapa titik yang terkontrol. Tingkat kerusakannya ratarata diatas 20 persen, maka hal itu menjadi hambatan Dinas Pekerjaan Umum dan
Penataan Ruang (PUPR) dalam melakukan pemeliharaan jalan dan penanganannya. Dinas Pekerjaan Umum dan Penataan Ruang (PUPR) juga melihat dari anggaran biaya, yaitu anggaran biaya yang kecil sekitar Rp. 3 miliar per tahun yang tersebar di kabupaten pandeglang dan itu untuk kegiatan pemeliharaan jalan, sedangkan pemeliharaan jalannya lebih banyak hingga melebihi kapasitas yang ada. Anggaran yang kecil melebihi kapasitas pemeliharaan jalan yang membutuhkan anggaran sangat besar akan berdampak pada tingkat kerusakan jalan yang 
lebih menjadi parah karena tidak diperbaiki, dengan anggaran yang sangat terbatas, akan memperparah kerusakan jalan dan akan menambah tingkat biaya lebih besar serta lebih menghambat jalannya pemeliharaan. Anggaran yang didapat yaitu dari APBD Kabupaten Pandeglang, Dana dari pusat berupa Dana Alokasi Khusus (DAK) dari kementrian keuangan, Bantuan keuangan Provinsi Banten, APBN langsung tetapi tidak dari keuangannya hanya berupa dari kegiatannya langsung.

Beberapa penelitian terdahulu tentang program pembangunan infrastruktur dikemukakan oleh Sururi (2015), bahwa untuk melaksanakan pembangunan daerah secara tepat, efektif dan efisien, dibutuhkan kredibilitas sumber daya manusia masyarakat dan kualitas aparatur pemerintahan yang mampu merumuskan dan memformulasikan kebijakan. Selanjutnya Prapti dan kawankawan (2015 dan Julianto (2015) menjelaskan terdapat pengaruh positif dan signifikan dari variabel infrastruktur jalan (X1) terhadap manfaat ekonomi (Y1) dapat diterima

Adanya pemeliharaan jalan dapat mempertahankan kondisi jalan sesuai dengan tingkat pelayanan dan kemampuannya pada saat jalan tersebut selesai dibangun dan dioperasikan sampai dengan tercapainya umur rencana yang telah ditentukan. Pemeliharaan jalan tidak hanya pada perbaikannya saja, namun mencakup pula pemeliharaan bangunan pelengkap jalan dan fasilitas beserta sarana-sarana pendukungnya. Banyaknya jumlah penggunaan jalan yang tidak seimbang dengan kondisi jalan yang sempit dan rusak sehingga mengakibatkan para pengemudi kendaraan mengalami kecelakan untuk tahun 2016 tingkat kecelakan sebanyak 223 kasus, 2017 sebanyak 168 kasus kecelakan ada penurunan dibandingkan tahun lalu karena penyebab kecelakaan juga masih banyaknya jalan-jalan yang berlubang, http://bantenheadline.com, 25 mei 2018, pukul 09.00. kurang pemeliharaan dan lambatnya penanganan terhadap perbaikan jalan akan dapat menghambat aktivitas masyarakat. hal tersebut menjadi masalah yang harus segera diselesaikan dan diperbaiki karena jalan merupakan prasarana transportasi darat yang digunakan oleh para pengemudi kendaraan roda empat maupun dua untuk bekerja, berdagang dan berkunjung ke suatu tempat maupun wisata, namun pada kenyataannya masih banyak jalan yang rusak baik di Kabupaten Pandeglang maupun di jalan-jalan lainnya.

Oleh karena itu Dinas Pekerjaan Umum dan Penataan Ruang (PUPR) membuat program untuk jalan serta mencakup pemeliharaan jalannya. Untuk itu pemeliharaan jalan di Kabupaten Pandeglang ini diharapkan akan dapat meningkatkan, membentuk, dan menjadikan kawasan yang memiliki daya tumbuh kembang perekonomian tanpa menimbulkan permasalahan yang cukup berarti bagi Dinas Pekerjaan Umum dan Penataan Ruang (PUPR) pemerintah Kabupaten Pandeglang secara keseluruhan, selain itu diharapkan dapat memperkuat perekonomian kota atau desa dimana pelaku didalamnya terdiri dari berbagai lapisan masyarakat. Berdasarkan dari beberapa fenomena yang terjadi, penelitian ini bertujuan untuk mengetahui bagaimana implementasi program Pemeliharaan Jalan di Dinas Pekerjaan Umum dan Penataan Ruang (PUPR) Kabupaten Pandeglang dan apa faktor pendukung dan penghambat dalam implementasi program pemeliharaan jalan di Dinas Pekerjaan Umum dan Penataan Ruang (PUPR)

\section{METODE PENELITIAN}

Metode yang digunakan dalam penelitian ini adalah penelitian dengan pendekatan kualitatif, yaitu penelitian dengan memahami fenomena apa yang dialami oleh subjek penelitian secara holistik dengan cara mendeskripsikan dalam bentuk kalimat. Tipe penelitian ini dengan menggunakan deskriptip kualitatif dimana peneliti mendeskripsikan atau mengkonstruksi pengamatan mendalam terhadap subjek yang diteliti dengan tujuan memperoleh informasi mengenai 
Implementasi Program Pemeliharaan Jalan di Dinas Pekerjaan Umum dan Penataan Ruang (PUPR) Kabupaten Pandeglang (Studi kasus Kecamatan Pandeglang), Teknik pengumpulan data dilakukan dengan tiga cara yaitu Observasi, wawancara dan dokumentasi, sedangkan teknik penentuan informan yaitu dengan taknik purposive sampling dimana sampel adalah orang-orang yang berkaitan satu sama lain dalam pemeliharaan jalan di Kabupaten Pandeglang. Sedangkan aspek pengumpulan data, peneliti senantiasa melakukan analisis yang terdiri dari tiga alur kegiatan yang terjadi secara bersamaan yaitu reduksi data, penyajian data, penarikan kesimpulan atau verivikasi ( Miles dan Huberman, 1992 : 21)

\section{Hasil Penelitian}

Berdasarkan data-data yang diperoleh, ada beberapa hal yang berkaitan dengan Implementasi Program, sehingga diperoleh hasil penelitian sesuai dengan kerangka pemikiran diawal yaitu mengenai Implementasi Program Pemeliharaan Jalan di Dinas Pekerjaan Umum dan Penataan Ruang (PUPR) Kabupaten Pandeglang dan yang kedua faktor pendukung dan penghambat dalam Implementasi Program Pemeliharaan Jalan yang menggunakan model Meriee S. Grindle untuk menghasilkan jawaban perumusan masalah dalam pemaparan mengenai hasil pengumpulan data yang dilakukan oleh peneliti untuk menunjang jawaban permasalahan yang diteliti, yaitu :

\section{HASIL PENELITIAN DAN PEMBAHASAN}

1. Implementasi Program Pemeliharaan Jalan di Dinas Pekerjaan Umum dan Penataan Ruang (PUPR) Kabupaten Pandeglang (Studi kasus Kecamatan Pandeglang)

Pemeliharaan jalan adalah salah satu kepentingan umum untuk menunjang kesejahteraan masyarakat dalam meningkatkan kualitas pelayanan yang ada, karena dengan adanya pemeliharaan jalan akan meningkatkan sarana dan prasarana agar masyarakat mendapat keamanan dan kenyamanan saat berkendara dijalan. Kecamatan Pandeglang merupakan salah satu Kecamatan yang melaksanakan program pemeliharaan jalan. Dengan adanya program pemeliharaan jalan ini diharapkan mampu meningkatkan pelayanan sarana dan prasarana, dapat mengurangi tingkat kerusakan jalan dan meningkatkan keamanan serta kenyamanan saat berkendara sesuai yang diharapkan masyarakat. Kondisi pemeliharaan jalan kabupaten Pandeglang untuk setiap jalan sudah cukup terpenuhi namun masih ada jalan-jalan yang kadang belum diperbaiki sama sekali. Dengan adanya program pemeliharaan jalan ini diharapkan mampu mengurangi kerusakan jalan yang ada sesuai yang diharapkan masyarakat. Tahun ini dinas pekerjaan umum dan penataan ruang menargetkan jalan yang ada dikabupaten Pandeglang termasuk jalan Cikupa, jalan Letnan Bolang, yang berada dikecamatan Pandeglang.

Pelaksanaan program pemeliharaan jalan dilakukan satu atau dua tahun sekali menyesuaikan kebutuhan masyarakat dan daerah, kewenangan yang diberikan pemerintah daerah dilaksanakan berdasarkan perencanaan atau program yang akan dilaksanakan setiap tahunnya, dengan adanya pelaksanaan pemeliharaan jalan maka pemerintah bisa meningkatkan kualitas pelayanan sarana dan prasarana kepada masyarakat. Manfaat yang diterima dari pemeliharaan jalan yaitu mempermudah kendaraan bermotor dan mobil atau kendaraan besar yang akan melaju, memberikan keselamatan bagi pengendara dan meningkatkan kualitas pelayanan sarana dan prasarana kepada masyarakat. Permasalahan pemeliharaan jalan di kecamatan Pandeglang yaitu masih banyak jalan-jalan yang belum diperbaiki atau dipelihara tidak hanya itu permintaan pemeliharaan jalan setiap tahun terus meningkat.

Program ini dibuat oleh pemerintah daerah disesuaikan dengan peraturan bupati Pandeglang nomor 54 tahun 2016 terkait 
tentang kedudukan, susunan organisasi, rincian tugas dan fungsi serta tata kerja dinas pekerjaan umum dan penataan ruang. Bupati dalam hal pemerintah daerah memberikan kewenangan kepada dinas pekerjaan umum dan penataan ruang dalam hal melaksanakan pemeliharaan jalan dan pelaksanaan pemeliharaan jalan yang dilakukan berdasarkan kewenangan jalan yang diberikan.

Teori yang digunakan oleh peneliti yaitu teori Meriee S. Grindle karena peneliti hanya meneliti bagaimana pentingnya masyarakat dalam pelaksanaan program pemeliharaan jalan, dilihat dari manfaat yang dihasilkan dari program pemeliharaan jalan, perubahan yang diinginkan kedepannya seperti apa, melihat dari letak pengambilan keputusannya seperti apa, pelaksanaan programnya bagaimana, sumber daya yang digunakan dalam program pemeliharaan jalan apa saja, strategi aktor yang terlibatnya seperti apa, dilihat dari tingkat kepatuhan dan respon dari pelaksana program seperti apa. Maka dari itu peneliti menggunakan teori Grindle yang menggunakan delapan indikator yaitu : kepentingan yang mempengaruhi, tipe manfaat, perubahan yang ingin dicapai, letak pengambilan keputusan, pelaksana program, sumber daya yang digunakan, strategi actor yang terlibat, kepatuhan dan respon dari pelaksana.

\section{Content of Policy/Isi kebijakan Kepentingan yang mempengaruhi}

Berkaitan dengan berbagai kepentingan yang mempengaruhi implementasi program pemeliharaan jalan dalam pelaksanaannya melibatkan banyak kepentingan dan melihat sejauhmana kepentingan tersebut membawa pengaruh terhadap implementasi program pemeliharaan jalan. Agar implementasi berjalan baik maka peneliti mengajukan pertanyaan mengenai Pentingkah peran masyarakat dalam pelaksanaan program pemeliharaan jalan karena kecamatan Pandeglang merupakan salah satu sasaran pelaksanaan program yang dilakukan oleh perintah daerah. Untuk Mengetahui seberapa jauh peran masyarakat dalam program pemeliharaan jalan. Berdasarkan uraian analisis dari hasil wawancara informan seksi pemeliharaan jalan, bidang bina progam dan kasubag UPT mengenai kepentingan yang mempengaruhi disini peran masyarakat dalam pelaksanaan program pemeliharaan jalan yang baik akan dapat mengasilkan implementasi yang baik pula. Dilihat dari pernyataan wawancara informan tersebut terkait dengan peran masyarakat dalam pelaksanaan program pemeliharaan jalan memang sangatlah penting karena masyarakat sebagai kelompok sasaran suatu program dan masyarakat juga sebagai pengguna jalan. Bila tidak dengan masyarakat program tersebut tidak akan berjalan dengan baik karena masyarakat yang mengetahui betul jalan-jalan mana saja yang harus segera diperbaiki. Menurut peneliti masyarakat sudah baik dalam menyampaikan pengaduan melalui twitter terkait jalan rusak dan bisa langsung disampaikan kepada pihak dinas PUPR. Sebagai contoh pada gambar mengenai pengaduan masyarakat melalui internet yang dirasa cukup efektif karena secara tidak langsung masyarakat bisa menyampaikan apa yang dikeluhkan terkait jalan rusak. Semakin banyak masyarakat mengadukan keluhan jalan yang rusak maka akan semakin cepat juga jalan rusak tersebut di tindak lanjuti dan diperbaiki.

Berikut ini contoh bentuk pengaduan masyarakat kepada dinas pekerjaan umum dan penataan ruang melalui website :

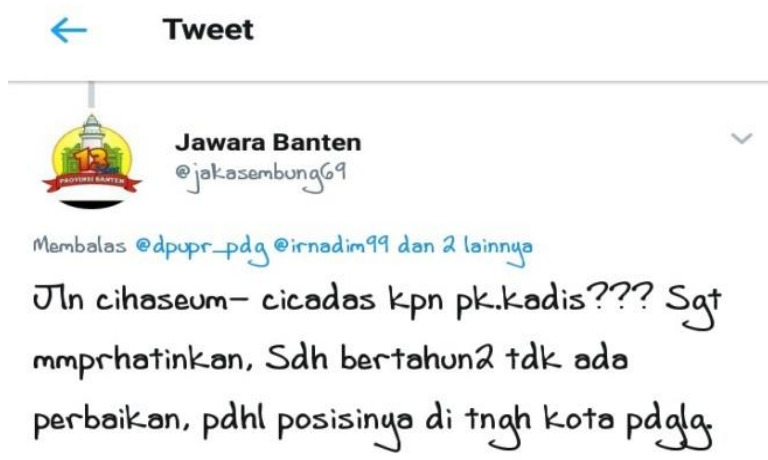




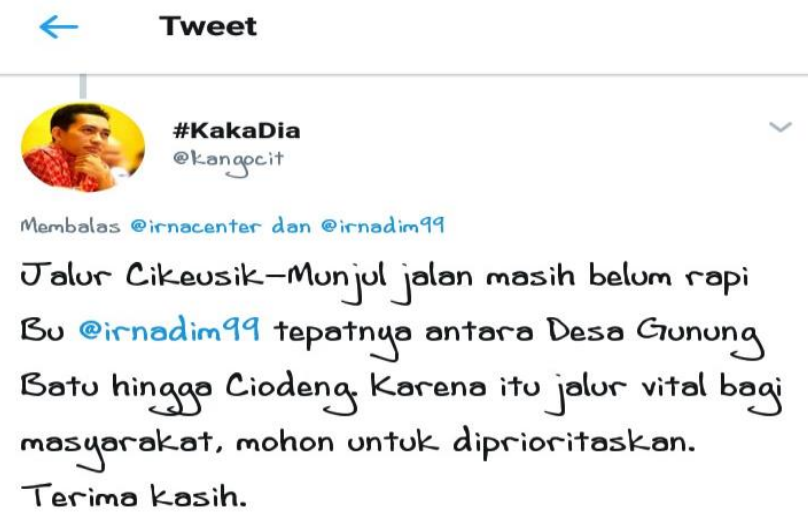

\section{Tipe manfaat}

Menurut Grindle menjelaskan bahwa dalam implementasi program pemeliharaan jalan harus terdapat beberapa jenis manfaat yang menunjukan dampak positif yang dihasilkan program pemeliharaan jalan yang dilaksanakan oleh dinas pekerjaan umum dan penataan ruang. Maka peneliti mengajukan pertanyaan terkait manfaat yang dihasilkan dari program pemeliharaan jalan.Berdasarkan analisis hasil wawancara seksi pemeliharaan jalan, bidang bina marga dan kasubag upt 1 terkait manfaat yang dihasilkan setelah jalan diperbaiki atau dipelihara tentunya banyak sekali manfaatnya terhadap pengguna jalan atau masyarakat, Begitu pun dalam kehidupan sosial masyarakat juga dapat meningkatkan ekonomi masyarakat dan tidak terhambat dalam kegiatan perekonomian serta memudahkan akses mobilitas perjalanan, lalu peneliti menanyakan hal mengenai manfaat yang diterima dari pemeliharaan jalan kepada masyarakat yang termasuk kedalam program pemeliharaan jalan, serta melakukan wawancara dengan staf pembangunan dikecamatan Pandeglang terkait manfaat yang dihasilkan dari program pemeliharaan jalan, ternyata warga Cikupa memperoleh manfaat dari pelaksanaan program pemeliharaan jalan karena program tersebut dapat mengurangi jalan yang rusak dan tidak akan membahayakan untuk para pengendara motor dan mobil, dengan begitu dapat memperpanjang waktu jalan agar bertahan cukup lama dan tidak cepat rusak kembali.

\section{Derajat perubahan yang ingin dicapai}

Setiap kebijakan mempunyai target yang hendak dan ingin dicapai. Content of policy yang ingin dijelaskan pada poin ini adalah bahwa seberapa besar perubahan yang hendak atau ingin dicapai melalui suatu implementasi kebijakan harus mempunyai skala yang jelas. Maka peneliti mengajukan pertanyaan mengenai perubahan yang ingin dicapai untuk kedepannya agar mengurangi tingkat kerusakan jalan

Berdasarkan analisis hasil wawancara dengan bidang Bina Marga, seksi pemeliharaan jalan mengenai perubahan yang ingin dicapai untuk kedepannya agar tidak ada lagi jalan yang rusak, sehingga akan meningkatkan pelayanan pemerintah daerah kepada masyarakat. Menurut analisa peneliti tersebut untuk perubahan pemeliharaan jalan dinas pekerjaan umum dan penataan ruang sudah melakukan tugasnya dengan baik dalam melaksanakan program pemeliharaan jalan tetapi memang tidak sedikit jalan yang harus dipelihara atau diperbaiki karena tingkat pengguna kendaraan yang semakin banyak tidak sebanding dengan konstruksi jalan yang sehingga bisa menyebakan jalan menjadi cepat rusak. Untuk itu dinas pekerjaan umum dan penataan ruang tiap tahun harus selalu ada anggaran perbaikan dan pemeliharaan jalan supaya meminimalisir jalan yang rusak agar memberikan pelayanan kepada masyarakat serta meningkatkan prasarana yang baik. Selain itu peneliti menanyakan perubahan yang ingin dicapai dan ternyata perubahan yang masyarakat inginkan terkait program pemeliharaan jalan kedepannya ingin semua jalan sudah bagus dan tidak ada lagi jalan-jalan yang rusak karena memang sangat mengganggu pengguna jalan. Dari pemerintah daerah dan dinas PUPR juga harus memberikan pelayanan yang baik kepada masyarakat terutama pemeliharaan jalan supaya tidak ada lagi jalan yang rusak dan akan menghambat pertumbuhan perekonomian juga perkembangan masyarakat. 


\section{Letak pengambilan keputusan}

Letak pengambilan keputusan dalam pelaksanaan suatu kebijakan, maka pada bagian ini harus dijelaskan dimana letak pengambilan keputusan dari suatu kebijakan yang akan diimplementasikan dan apakah letak program tersebut sudah tepat dilaksanakan. Maka peneliti mengajukan pertanyaan mengenai letak pengambilan keputusan program yang dilaksanakan di kecamatan Pandeglang tersebut sudah benar, menurut seksi pemeliharaan jalan kabupaten dinas pekerjaan umum dan penataan ruang

Berdasarkan hasil wawancara dengan seksi pemeliharaan jalan, kasubag upt 1 dan staf pembangunan Kecamatan Pandeglang terkait letak keputusan program yang dilaksanakan di kecamatan Pandeglang tersebut sudah benar karena di kecamatan Pandeglang masih banyak sekali jalan yang rusak dan tidak terpelihara dengan baik padahal jalan tersebut berada di dekat kota. Karena aktivitas masyarakat dengan jumlah penduduk yang semakin meningkat tidak sebanding dengan kondis jalan yang sempit dan rusak yang bisa mengakibatkan masyarakat pengguna jalan mengalami kecelakaan karena rusaknya jalan, kurangnya pemeliharaan dan lambatnya penanganan terhadap perbaikan. Berdasarkan analisa peneliti menyimpulkan bahwa dalam pelaksanaan program pemeliharaan jalan yang di laksanakan dinas pekerjaan umum dan penataan ruang di kecamatan Pandeglang itu sudah benar tetapi memang tidak semua jalan dipelihara atau diperbaiki hanya sebagian saja yang sudah dipelihara, walaupun tidak semua jalan di pelihara ataupun diperbaiki tetapi pihak dinas pekerjaan umum dan penataan ruang sudah memberikan pelayanan terhadap keinginan masyarakat dapat terpenuhi dengan baik, dan kedepannya dinas pekerjaan umum dan penataan ruang bisa lebih meningkatkan pemeliharaan jalan di kecamatan Pandeglang.

\section{Pelaksana Program}

Dalam menjalankan kebijakan atau program harus di dukung adanya pelaksana kebijakan yang kompeten dan kapabel demi keberhasilan suatu kebijakan. Dan ini harus sudah terdaftar atau terpapar dengan baik pada bagian ini maka peneliti mengajukan pertanyaan mengenai apakah pelaksana sudah kompeten dan mampu dalam melaksanakan program pemeliharaan jalan, Berdasarkan hasil wawancara seksi pemeliharaan jalan, bidang bina marga diatas mengenai apakah pelaksana sudah kompeten dan mampu dalam melaksanakan program pemeliharaan jalan. Menurut dinas pekerjaan umum dan penataan ruang maupun dari setiap bidang dan upt semua sudah memiliki kemampuan yang berkompeten dalam melaksanakan setiap kegiatan jalan, irigasi ataupun bangunan karena menyesuaikan dengan kemampuan yang dimiliki setiap bidangnya masingmasing. Bila dalam pelaksanaan tidak diikuti dengan pelaksana yang sudah kompeten maka akan menyebabkan kegiatan itu tidak berjalan dengan baik dan efektif.

\section{Sumber daya yang digunakan}

Pelaksanaan suatu kebijakan juga harus di dukung oleh sumberdaya yang mendukung, agar pelaksanaan program pemeliharaan jalan dapat berjalan dengan baik. Program pemeliharaan jalan merupakan suatu kebijakan yang mana dalam pelaksanaannya membutuhkan sumberdaya yang memadai agar program tersebut dapat berjalan dengan baik. Dalam teori grindle tidak ada indikator yang jelas karena penelitian ini menggunakan sumberdaya manusia, sumberdaya finansial dan sumberdaya waktu namun dalam teori grindle tidak diperjelas indikator tersebut, maka peneliti merekomendasikan teori penunjang dari Van Metter dan Van Horn mengenai sumberdaya yaitu sumber daya manusia, sumberdaya finansial dan sumberdaya waktu karena keberhasilan implementasi kebijakan juga sangat tergantung pada sumberdaya yang tersedia. 
Sumberdaya finansial

Dalam pelaksanaan kebijakan sumberdaya finansial akan sangat berperan penting dalam pelaksanaan kebijakan dan keberhasilan suatu kebijakan. Dengan adanya sumberdaya finansial yang memadai dan tercukupi maka untuk melaksanakan kebijakan tersebut akan ada harapan bahwa pelaksanaannya akan berjalan dengan efektif. Dalam pelaksaan nya anggaran yang dibutuhkan untuk program pemeliharaan jalan ini membutuhkan cukup banyak anggaran dan jika program pemeliharaan jalan ini ingin berhasil maka anggaran pun harus tercukupi dengan baik. Sementara itu terkait sumberdaya finansial anggaran untuk program pemeliharaan jalan ini berasal dari dana APBD. Seperti yang disampaikan oleh bidang bina program dinas pekerjaan umum dan penataan ruang. Tetapi untuk pemeliharaan jalan anggaran yang digunakan dari APBD tidak semua jalan dapat dipelihara hanya yang sudah di anggarkan saja sesuai dengan keputusan dan prioritasnya. Berikut data jalan yang termasuk dalam program pemeliharaan jalan di kecamatan Pandeglang

\section{Tabel 3}

Jalan yang termasuk dalam program pemeliharaan jalan anggaran tahun 2017

\begin{tabular}{|c|c|c|}
\hline No & Nama jalan & Anggaran \\
\hline 1 & $\begin{array}{c}\text { Komplek } \\
\text { perkantoran cikupa }\end{array}$ & $\begin{array}{c}\text { Rp. } \\
368.301 .000\end{array}$ \\
\hline 2 & Jalan letnan bolang & $\begin{array}{c}\text { Rp. } \\
286.260 .000\end{array}$ \\
\hline 3 & $\begin{array}{c}\text { Pandeglang- } \\
\text { Cicadas }\end{array}$ & $\begin{array}{c}\text { Gagal } \\
\text { Lelang }\end{array}$ \\
\hline
\end{tabular}

Sumber : PUPR kabupaten Pandeglang, 2017

Dari keterangan tabel diatas bahwa tahun 2017 dinas pekerjaan umum dan penataan ruang melaksanakan program pemeliharaan jalan di kecamatan pandeglang yang berjumlah 2 titik jalan yaitu di Komplek Perkantoran Cikupa dan Jalan Letnan Bolang. Tetapi untuk tahun 2017 pelaksanaan program pemeliharaan jalan ada satu jalan yang gagal lelang yaitu jalan Pandeglang-Cicadas dikarenakan tidak ada kriteria yang sesuai dari pihak ketiga yang di inginkan dari Dinas
Pekerjaan Umum dan Penataan Ruang, maka pelaksanaan program pemeliharaan jalan ini akan dilaksanakan di tahun berikutnya.

Berikut beberapa gambar jalan yang mengalami perbaikan

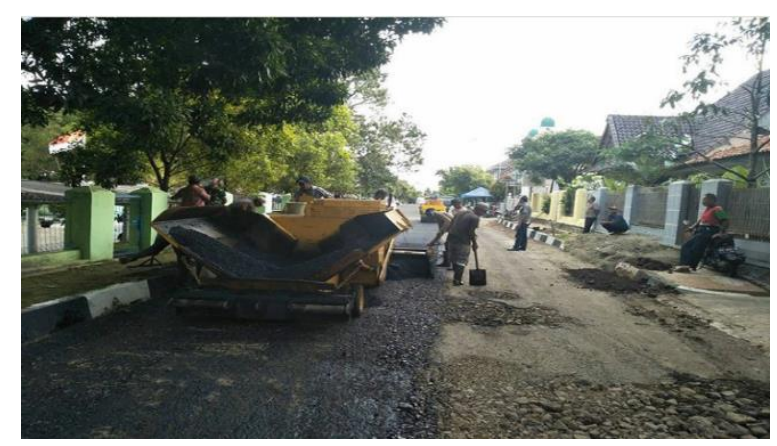

Gambar 3

Jalan yang sedang dilakukan pemelihaaran

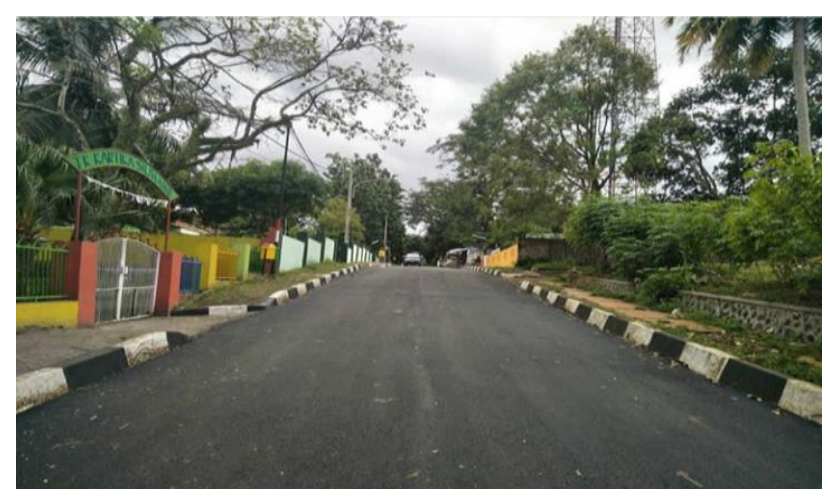

Gambar 4

Pemeliharaan jalan yang dilaksanakan di jalan Letnan Bolang yang masuk dalam program tahun 2017

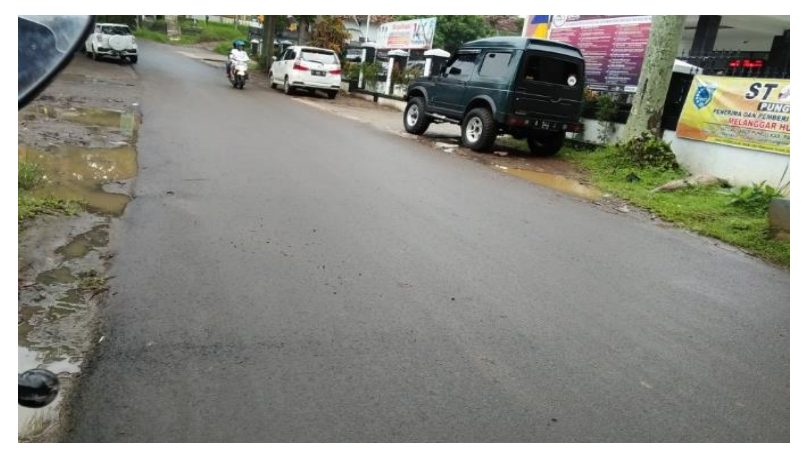

Gambar 5

Pemeliharaan jalan yang sudah

dilaksanakan dikomplek perkantoran cikupa yang masuk dalam program tahun 2017 
Berdasarkan analisis dari kutipan hasil wawancara seksi pemeliharaan jalan dan bidang bina marga terkait dengan pihak ketiga yang membantu dalam melaksanakan perbaikan ataupun pemeliharaan jalan yaitu adanya suatu kerjasama antara dua pihak yakni dinas pekerjaan umum dan penataan dengan pihak ketiga, dalam proses kerja sama dengan pihak ketiga melalui tender dengan proses lelang di ULP ( unit layanan pengadaan barang dan jasa). Bila anggaraan tersebut mendapatkan dana 50 juta kebawah maka pelaksanaannya akan dilakukan oleh upt (unit pelaksa teknis). Bila mendapatkan anggaraan diatas 200 juta maka ada proses lelang oleh pihak ketiga atau pemborong tetapi bila mendapatkan anggaran di bawah 200 juta maka ada proses penunjukan atau pemilihan langsung oleh dinas pekerjaan umum dan penataan ruang lalu dari ULP bagian dari pemerintah kabupaten Pandeglang yang melakukan proses informasi yang akan dilelangkan. Yang menawarkan dari pihak perusahaan mana setelah ada perhitungan perusahaan itu menang otomatis ada perjanjian kerjasama dengan dinas PUPR. Berdasarkan sudut pandang peneliti bahwa proses lelah tersebut bisa dilakukan secara online dan bila perusahaan tersebut sudah mendapatkan tender maka proses selanjutnya untuk pelaksanaannya pihak dinas pupr menentukan berapa hari pelaksanaannya, spek nya seperti apa. Untuk sumberdaya manusia memang sudah tercukupi dan disesuaikan dengan tugasnya masing-masing dan dalam pelaksaan tersebut bisa bisa terselesaikan dengan cepat akan menunjukan keberhasilan suatu implementasi ke

\section{Sumberdaya waktu}

Dalam melaksanakan kebijakan ataupun program bila waktu pelaksanaan itu melebihi yang sudah di tentukan maka kebijakan ataupun program akan berdampak kepada keberhasilan implementasi. Maka peneliti menanyakan berapa lama waktu yang dibutuhkan dan bagaimana bila melebihi batas waktu yang sudah ditentukan. Menurut seksi pemeliharaan jalan dinas pekerjaan umum dan penataan ruang bijakan.

Berdasarkan hasil analisis wawancara seksi pemeliharaan jalan dan kasubag upt wilayah 1 diatas terkait bagaimana bila melebihi batas waktu yang ditentukan sebelumnya dari wawancara diatas sudah dijelaskan oleh narasumber bahwa bila batas waktu dikarenakan cuaca atau bencana yang tidak di inginkan maka akan ditambahkan waktu pelaksanaannya dan itu tidak dikenakan denda bila pihak ketiga sanggup untuk melanjutkannya tetapi bila melibihi batas waktu dikarenakan kelalaian oleh pihak ketiga maka akan dikenakan sanksi dan denda. Menurut peneliti bila melebihi batas waktu yang ditentukan maka akan menghambat jalan itu untuk diperbaiki secepatnya dan malah bisa memperlambat pekerjaan jalan, dari dinas pupr sendiri harus bertindak lebih lagi dan memantau disetiap pekerjaan itu agar tidak terjadi hal-hal yang bisa merugikan pelaksanaannya. Dan lebih diperhatikan lagi dalam bekerjasama dengan pihak ketiga.

\section{Context of policy/ konteks implementasi Strategi aktor yang terlibat}

Dalam suatu kebijakan perlu diperhitungkan pula strategi yang digunakan oleh para actor yang terlibat guna memperlancar jalannya pelaksanaan suatu implementasi kebijakan. Bila hal ini tidak diperhitungkan dengan matang sangat besar kemungkinan program yang hendak diimplementasikan akan jauh arang dari api. Maka peneliti menanyakan bagaimana strategi yang dilakukan oleh pelaksana dalam menjalankan suatu program pemeliharaan jalan.

Berdasarkan hasil analisis wawancara seksi pemeliharaan jalan dan bidang bina marga diatas terkait strategi dari pelaksana dalam melaksanakan suatu program yaitu tercapainya target ruas jalan yang bisa dipelihara ataupun diperbaiki untuk memaksimalkan pencapaian yang bisa tertangani oleh dinas pekerjaan umum dan 
penataan dan pemerintah daerah itu berapa. Menurut peneliti terkait strategi yang dilakukan oleh dinas pupr itu sudah melakukan tugasnya dalam melaksanakan program dan harus memperhitungkan dengan baik agar bisa meningkatkan kualitas pelayanan terutama dalam jalan karena semua masyarakat, pemerintah daerah pasti menggunakan jalan ini.

\section{Kepatuhan dan respon dari pelaksana}

Proses pelaksanaan kebijakan berpengaruh terhadap kepatuhan dan respon dari pelaksana yang melaksanakan program pemeliharaan jalan dan sejauhmana pelaksana dalam menanggapi suatu kebijakan. Maka peneliti mengajukan pertanyaan terkait kepatuhan yang dilakukan oleh pelaksana program dan bagaimana respon pelaksana dalam menanggapi keluharan masyarakat terkait jalan yang rusak. Hal tersebut disampaikan oleh seksi pemeliharaan jalan kabupaten dinas pekerjaan umum dan penataan ruang

Berdasarkan hasil analisis wawancara kepada masyarakat Kecamatan Pandeglang dan warga Cikupa terkait respon dinas pekerjaan umum dan penataan ruang dalam menanggapi keluhan masyarakat mengenai jalan rusak memang dinas pupr sudah cukup baik dalam merespon jalan-jalan mana saja yang rusak yang harus diperbaiki dan dari pihak upt juga langsung terjun kelapangan dengan meninjau jalan yang memang membutuhkan pemeliharaan dan perbaikan. Menurut peneliti memang dinas pupr dan upt sudah baik dalam merespon keluhan-keluhan masyarakat dan mematuhi peraturan yang dibuat pemerintah daerah yang menyesuaikan dengan tugas masing-masing disetiap bidang, tetapi memang untuk melaksanakan perbaikan jalan dari pihak dinas pekerjaan umum dan penataan ruang tidak langsung diperbaiki dan dipelihara saat itu juga masyarakat harus menunggu cukup lama untuk diperbaiki karena memang menyesuaikan dengan kebutuhan dan prioritas jalannya. Tidak semua jalan bisa dipelihara dan diperbaiki oleh dinas pupr karena melihat dari anggaran yang memang harus di siapkan dari jauh-jauh hari agar tercukupi dan jalan yang rusak bisa tercover semua, memang butuh proses dalam melaksanakan suatu kegiatan itu tidak bisa langsung dipelihara dan diperbaiki begitu saja, kedepannya semoga dinas pupr dan semua pelaksana program pemeliharaan jalan bisa memberikan pelayanan yang baik kepada masyarakat dengan meningkat prasarana terutama jalan dan bisa mengurangi jumlah krusakan jalan di pandeglang ini.

pandeglang ini.

\section{Faktor pendukung dan Faktor penghambat}

Dalam pelaksanaan program pemeliharaan jalan ini untuk menentukan kegagalan dan keberhasilan suatu implementasi dapat dilihat dari faktor pendukung dan faktor penghambat dalam melaksanakan suatu program. Dua faktor ini tidak dapat dipisahkan dari kebijakan manapun terutama pada program pemeliharaan jalan ini dan bisa mengetahui berhasil atau tidak program pemeliharaan jalan.

Yang masuk menjadi salah satu dalam mendapatkan program pemeliharaan jalan yaitu Kecamatan Pandeglang. Berdasarkan hasil wawancara peneliti bahwa telah ditemukan beberapa faktor pendukung dalam pelaksanaan pemeliharaan jalan. Hal tersebut disampaikan oleh seksi pemeliharaan jalan dinas

Berdasarkan analisis hasil wawancara mengenai factor pendukung internal maupun ekternal yaitu adanya peraturan-peraturan dan sikap kepatuhan terhadap aturan yang berlaku yang disesuaikan dengan fungsi dan tugasnya masing-masing, selain itu adanya anggaran yang menjadi faktor pendukung dalam pelaksanaan program dan mendapatkan pembiayaan anggaran lain yang didapatkan dari DAK, APBN, Menteri keuangan dan provinsi yang bisa menambahkan anggaran untuk memperbanyak program khususnya jalan yang akan di perbaiki atau dipelihara 
serta sumberdaya manusianya yang memadai dan melaksanakan tugas serta kewajiban yang harus pelaksana jalankan.

Dalam proses pelaksanaannya program pemeliharaan jalan ini memiliki beberapa faktor penghambat. Yang pertama adalah faktor cuaca, bila faktor cuaca tidak mendukung disaat melaksanakan pemeliharaan maka akan menghambat untuk jalan diperbaiki dan akan menjadi lama dalam prosesnya. Faktor cuaca tidak bisa diukur oleh manusia dan tidak bisa diprediksi. Bisa juga anggaran yang kurang memadai dan terbatas menjadi faktor yang menghambat untuk cepat diperbaiki dengan kondisi yang kurang baik juga cukup besar, akses jalan untuk menuju ke tempat tujuan bisa saja menjadi penghambat

Dari hasil petikan wawancara diatas bahwa benar faktor penghambat dalam pelaksanaannya bisa dari cuaca yang bisa menghambat suatu pelaksanaan yang sedang berlangung dan bisa saja menjadi kendala yang tidak bisa diprediksikan. Faktor cuacalah yang mampu menjadi tolak ukur suatu keberhasilan implementasi. Kedua, anggaran yang kurang memadai juga bisa menjadi pengambat finansial karena terlalu banyaknya jalan-jalan yang harus segera di tangani dan diperbaiki maka anggaran yang didaptkan tidak cukup mampu memperbaiki semuanya. Ketiga, akses jalan yang tidak pernah diperbaiki sama sekali apalagi yang masih berbatu dan bertanah itu juga bisa menghambat untuk kesana terlebih lagi bila daerah yang jauh dan terpelosok.

\section{KESIMPULAN}

Berdasarkan hasil penelitian, secara keseluruhan dapat disimpulkan bahwa dalam pelaksanaan Program Pemeliharaan Jalan di Dinas Pekerjaan Umum dan Penataan Ruang (PUPR) Kabupaten Pandeglang (Studikasus Kecamatan Pandeglang) dapat disimpulkan bahwa program ini sudah berjalan dengan baik dan disesuaikan dengan pelaksanaannya hal ini bisa dilihat dari pelayanan yang diberikan pemerintah daerah ataupun Dinas
Pekerjaan Umum dan Penataan Ruang (PUPR) tetapi memang tidak bisa semua diperbaiki ataupun dipelihara karena melihat dari anggaran yang diberikan pemerintah daerah hanya untuk beberapa jalan yang diputuskan dan di prioritaskan tidak sebanding dengan banyaknya jalan yang harus diperbaiki dan dipelihara. Dalam melaksanaan pemeliharaan jalan ada banyak faktor mempengaruhi pelaksanaan di Kecamatan Pandeglang.

\section{DAFTAR PUSTAKA}

Agustino. Leo, 2012. Dasar-Dasar Kebijakan Publik. Bandung : Alfabeta

Djunaidi. Edi (2013) Implementasi Pembangunan Jalan Lingkungan Masyarakat Dalam Peningkatan Pelayanan Publik Pada Dinas Cipta Karya Dan Tata Kota. Samarinda : Universitas Mulawarman

Hamdi. Muchlis, 2014. Kebijakan Publik: Proses, analisis, partisipasi. Bogor : Ghalia Indonesia

Hartini. Sri (2012) Implementasi Kebijakan Pengelolaan Jalan di Kabupaten Banyumas. Purwokerto : Universitas Jenderal Soedirman

Hadiwardoyo. P. Sigit (2015) Implementasi Data Mining untuk Mendukung Sistem Mnajamen Perkerasan Jalan di Indonesia. Depok : Universitas Indoesia

Julianto Hendra, Jumario Noptri, Pengaruh Pembangunan Infrastruktur Jalan Terhadap Penataan Kawasan Kumuh Pesisir Kota Tarakan, Jurnal Potensi.

Lulus Prapti NSS, Suryawardana Edy dan Triyani Dian, 2015. Analisis Dampak Pembangunan Infrastruktur Jalan terhadap Pertumbuhan Usaha 
Ekonomi Rakyat di Kota Semarang, j. Dinamika Sosbud Volume 17 Nomor 2, Juni $2015: 82$ - 103

Mulyadi. Deddy, 2016. Studi Kebijakan Publik dan Pelayanan Publik. Bandung : ALFABETA

Sugiyono, 2014. Metode Penelitian Kuantitatif Kualitatif dan $R \& D$. Bandung : ALFABETA

Suharto. Edi, 2014. Membangun Masyarakat Memberdayakan Rakyat. Bandung : PT. Revika Aditama

Suharto. Edi, 2013. Kebijakan Sosial Sebagai Kebijakan Publik. Bandung : Alfabeta

Sururi, Ahmad, 205. Pemberdayaan Masyarakat melalui Program Pembangunan Infrastruktur Perdesaan dalam Meningkatkan Kesejahteraan Masyarakat Kecamatan Wanasalam Kabupaten Lebak, Jurnal Sawala Administrasi Negara, Volume 3 Nomor 2, Januari-April, Halaman 125.

Tahir. Arifin, 2014. Kebijakan Publik dan Transparansi Penyelenggaraan Pemerintah Daerah. Bandung : Alfabeta

\section{Dokumen-dokumen}

Peraturan Bupati Pandeglang nomor 54 tahun 2016 tentang kedudukan, susunan organisasi, rincian tugas dan fungsi serta tata kerja Dinas Pekerjaan Umum Dan Penataan Ruang

Peraturan Menteri Pekerjaan Umum, Nomor 13 tahun 2011 Tentang Tata Cara Pemeliharaan Jalan dan Penilikan
Keputusan Menteri Pekerjaan Umum dan Perumahan Rakyat, Nomor 248 tahun 2015 Tentang Penetapan Ruas Jalan Provinsi

Keputusan Gubernur Banten, Nomor 620 Tahun 2016 Tentang Penetapan Jalan Provinsi Banten

Keputusan Bupati Pandeglang, Nomor 620 Tahun 2009 Tentang Daftar Induk Jalan Kabupaten Pandeglang

http://mtrpbs.rehabilitasi-dan-pemeliharaanbangunan.co.id/2009/10/, 3 maret 2017, Pukul 21.19

https://www.scribd.com/doc/94391322/Perme n-PU-Nomor-13, 10 maret 2017, pukul 09.35

http://bantenheadline.com, 25 mei 2018, pukul 09.00

Dinas Pekerjaan Umum dan Penataan Ruang (PUPR) 